\title{
The Structure of Model for New Services Development
}

\author{
Povilas Švogžlys \\ Department of Management, Faculty of Business Management, Vilnius Gediminas \\ Technical University, Sauletekio al. 11, LT-10223, Vilnius, Lithuania \\ povilas.svogzlys@vgtu.lt
}

\begin{abstract}
The development of new services is an important strategic step for companies that want to gain a competitive advantage in the services sector. The models for new service development can be considered as business tools contributing to more efficient idea generation, job allocation, consumer engagement or overall process of management. Despite the fact that there are many works of research about the models oriented towards the development of new services, the process of formation has been analysed in a very fragmented way without justifying the principles of how to choose the components. Taking the previous-mentioned aspects into account, this article will consistently provide the scientific bases, needs, and benefits of choices of the type, stages and other components of the new model for new service development (Skačkauskiene et al. 2019). The methods of benchmarking, synthesis and complex generalization were used in the research.
\end{abstract}

Keywords: New service development, structure, stages, composition, elements, components.

\section{Introduction}

The idea of models oriented towards the management of the process of a new service development can be easily found in many modern scientific works (Shekar, 2007; Burger et al., 2010; Lin and Hsieh, 2011; Edvardsson et al., 2013; Santos and Spring, 2013; Santana et al., 2016). It is noticeable that the structures of new service development models are becoming more unique, while the models themselves are oriented towards solving internal or external problems of an organization: E. Stevens and S. Dimitriadis (2005) have presented Systemic Learning Model for New Service Development, C. M Froehle and A. V. Roth (2007) have introduced Resource-Process Framework of New Service Development. o D. Jin et al. (2014) 
have proposed New Service Development Maturity Model. It is also noticeable that the authors tend to dedicate the new models to solve problems prevailing in a particular sector. This tendency is reflected in the model titled A Model of NSD for Tourism Services proposed by R. Dalton et al. (2009).

Even though the scientific literature offers to choose from a large number of models for new service development, but the general process of formation and choices of the individual components have been analysed fragmented. The lack of scientific basis for the demand of such models, the choices of their stages and other components is noted. Usually, it is not clear why specific components have been chosen, how they interact with each other, in what dimensions they could operate, and what positive impact they could have on the process of new service development. Taking the previous-mentioned aspects into account, this article will consistently provide the scientific bases, needs, and benefits of choices of the type, stages and other components of the new model for new service development (Skačkauskienė et al., 2019), as well as, the directions for further research are presented.

\section{The Scientific Basis for the Type Choice of a Model for New Services Development}

Usually, the process of formation and all distinctive features of a model for new service development depend on the specific type of a model. The type can affect the overall structure of a model, the layout of the actions that have to be performed, and in some cases, even the actions of a consumer might be dictated by the specific type. E. Stevens and S. Dimitriadis (2005) have noted 3 the main disadvantages of the cyclical and linear models on condition that these models belong to the type of sequential development models:

1. Implementing the stage-gate systems in practice, the bureaucratic processes might be faced, as a result, the overall process of development would be restricted.

2. The description of the stages does not include the exact ways of how companies should organize the process of implementation.

3 . The cyclic and linear models do not define what exactly might be developed during every stage.

M. Reinoso et al. (2009) have conducted a comparative analysis of new product and service development models and found out that the previous-mentioned models are not detailed enough. Other scholars who have analysed the differences of types of models for new service development agree with this statement: P. P. Wang et al. (2011); M. Rapaccini et al. (2013); B. Edvardsson et al. (2013). D. C. Wynn and P. J. Clarkson (2018) have analysed the project management and engineering of more than 20 models related to new services and products development, found out that high level of abstraction of the sequential development models does not the detailed guidelines about the improvements of the situation and solutions. 
Table 1: Classification by specific types of new service development models

\begin{tabular}{|c|c|c|c|c|c|}
\hline \multirow[b]{3}{*}{ 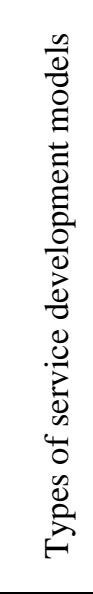 } & \multicolumn{4}{|c|}{ Classification by specific types of new service development models } & \\
\hline & 1 group & 2 group & 3 group & 4 group & \\
\hline & $\begin{array}{c}\text { Structure of } \\
\text { models } \\
\text { defined (1); } \\
\text { more defined } \\
\text { than indefinite } \\
(2) ; \\
\text { more indefinite } \\
\text { than defined (3); } \\
\text { indefinite (4) }\end{array}$ & $\begin{array}{l}\text { Layout of actions } \\
\text { consistent (1); } \\
\text { more consistent } \\
\text { than inconsistent } \\
\text { (2); } \\
\text { more inconsistent } \\
\text { than consistent } \\
(3) ; \\
\text { free (4) }\end{array}$ & $\begin{array}{c}\text { Completeness of } \\
\text { models } \\
\text { incomprehensive (1); } \\
\text { more } \\
\text { incomprehensive than } \\
\text { comprehensive (2); } \\
\text { more comprehensive } \\
\text { than incomprehensive } \\
\text { (3); } \\
\text { comprehensive (4) }\end{array}$ & $\begin{array}{l}\text { Inclusion of } \\
\text { external } \\
\text { dimension } \\
\text { difficult (1); } \\
\text { more difficult } \\
\text { than easy (2); } \\
\text { more easy } \\
\text { than difficult } \\
\text { (3) } \\
\text { easy (4) }\end{array}$ & 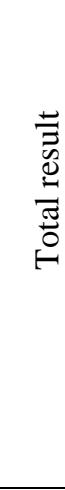 \\
\hline $\begin{array}{l}\frac{n}{0} \\
\frac{0}{0} \\
\vdots \\
0 \\
0 \\
0 \\
0 \\
U\end{array}$ & $\begin{array}{c}\text { More defined } \\
\text { than indefinite - } \\
2 \\
\text { (Froehle and } \\
\text { Roth, 2007; } \\
\text { Dalton et al., } \\
\text { 2009; } \\
\text { Jin et al., 2014) }\end{array}$ & $\begin{array}{c}\text { Consistent }-1 \\
\text { (Stevens, } \\
\text { Dimitriadis 2005; } \\
\text { Froehle, Roth } \\
\text { 2007; Dalton } \text { et } \\
\text { al., 2009; } \\
\text { Jin et al., 2014) }\end{array}$ & $\begin{array}{c}\text { More } \\
\text { incomprehensive than } \\
\text { comprehensive }-2 \\
\text { (Dalton } \text { et al., 2009; } \\
\text { Jin } \text { et al., 2014) }\end{array}$ & $\begin{array}{c}\text { More difficult } \\
\text { than easy }-2 \\
\text { (Johnson } \text { et } \\
\text { al., 2000; } \\
\text { Stevens, } \\
\text { Dimitriadis } \\
2005 ; \\
\text { Dalton et al., } \\
\text { 2009) }\end{array}$ & 7 \\
\hline 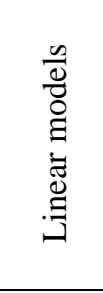 & $\begin{array}{l}\text { Defined - } 1 \\
\text { (Shekar, 2007; } \\
\text { Burger et al., } \\
\text { 2010) }\end{array}$ & $\begin{array}{c}\text { Consistent }-1 \\
\text { (Alam and Perry, } \\
\text { 2002; } \\
\text { Stevens and } \\
\text { Dimitriadis, 2005.) }\end{array}$ & $\begin{array}{c}\text { More } \\
\text { incomprehensive than } \\
\text { comprehensive }-2 \\
\text { (Lin and Hsieh, 2011; } \\
\text { Burger } \text { et al., 2010; } \\
\text { Santana } \text { et al., 2016.) }\end{array}$ & Difficu & 5 \\
\hline 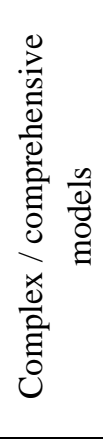 & $\begin{array}{c}\text { More indefinite } \\
\text { than defined }-3 \\
\text { (Gaus et al., } \\
\text { 2013; Yu, } \\
\text { Sangiorgi, 2014; } \\
\text { Hsu, 2017.) }\end{array}$ & $\begin{array}{c}\text { More inconsistent } \\
\text { than consistent }-3 \\
\text { (Edvardsson } \text { et al., } \\
\text { 2013; Gaus } \text { et al., } \\
\text { 2013; } \\
\text { Santos and Spring, } \\
\text { 2013.) }\end{array}$ & $\begin{array}{c}\text { More comprehensive } \\
\text { than incomprehensive } \\
\quad-3 \\
\text { (Santos and Spring, } \\
\text { 2013; Drejeris, 2015; } \\
\text { Hsu, 2017.) }\end{array}$ & $\begin{array}{c}\text { More easy } \\
\text { than difficult - } \\
3 \\
\text { (Gaus } \text { et al., } \\
2013 ; \\
\text { Yu and } \\
\text { Sangiorgi, } \\
\text { 2014; } \\
\text { Hsu, 2017.) }\end{array}$ & 12 \\
\hline
\end{tabular}

Source: Compiled by the author.

The scientific literature also provides insights about the weaknesses of complex/ 
comprehensive models that belong to another category of models for new service development. S. Cocca et al. (2015) observe that this type of model requires a higher level of knowledge application. This statement is supported by G. Briscoe et al. (2012) as well, they confirm the idea that the knowledge base should be increased together with the number of actions.

The identified weaknesses urge to have a broader view of the characteristics of models for new service development. The cyclic, linear, and complex/ comprehensive models were compared according to the features of four groups: structure, the layout of actions, the particularity of a model, and the ability to integrate the external actions (see Table 1).

Some researchers (Katinienė, 2018; Kopańska, 2017; Kumar and Singh, 2017; Chawla et al., 2012) assign the numerical values to models after evaluating objects, their species or attributes by using the method of benchmarking. According to J. H. Zanker and R. Mallett (2013), the numerical values make it easier to classify and analyse data during the theoretical evaluation. After the examination of sizes and ranges of numerical values found in the scientific literature, several aspects were noticed:

1. The most common ranges of the numerical values are small and vary from 1 to 3 or 1 to 5 (Katinienè, 2018; Kopańska, 2017; Kumar and Singh, 2017; Chawla et al., 2012).

2. Only the expressions of natural numbers are used as numerical values.

3. The numerical values are used to base the choice of the most beneficial result (Katinienè, 2018; Kumar and Singh, 2017).

Considering these insights, the numerical values from 1 to 4 were assigned to every group. This range was selected because every type of model for new service development has been evaluated according to the four groups of features.

The results of the analysis have revealed the weaknesses and strengths of different types of models for new service development:

1. The cyclic and linear models have a relatively limited structure that makes it difficult to form or develop a model. It was noticed that the shape of cyclic models is more convenient to make the structural interpretations. However, both of these types require to follow certain rules in order to keep the "original" form of these models.

2. All actions of the cyclic and linear models are arranged sequentially, as a result, one action can be related to one or two other successive actions. Meanwhile, the distinguished action of the complex/ comprehensive models can be related to a larger number of actions (Edvardsson et al., 2013; Santos, Spring 2013; Hsu 2017).

3. Usually, the cyclic and linear models of new service development have the specified sequence of actions that must be adopted by the business subject. I. Alam, C. Perry (2002), H. J. Bullinger, P. Schreiner (2006), T. Burger et al. (2010), F. Lin, P. Hsieh (2011) and F. E. Santana et al. (2016) have tried to solve this problem in 
the presented models of new service development. The authors have prepared the additional tasks that might be done by the businesses subject at each stage of the new service development. However, only the role of employees has been highlighted.

4. The cyclical and linear models do not include the dimensions that might have an impact on the development of new services: consumers, competitors, suppliers, etc. S. P. Johnson et al. (2000), E. Stevens, S. Dimitriadis (2005) and R. Dalton et al. (2009) have tried to eliminate this disadvantage of the cyclic models. However, the upgraded models presented by the authors do not fully reveal neither the connection between internal and external dimensions nor the overall connection between them. It was noted, in case of complex models, the external actions which might have an impact on the process of new service development are distinguished (Edvardsson et al., 2013; Gaus et al., 2013), as well as, the individual dimensions where the actions might be performed are formulated too (Yu and Sangiorgi, 2014; Hsu, 2017; Santos and Spring, 2014).

\section{The Scientific Basis for the Choice of Stages for a Model for New Services Development}

The scientific literature is still facing a lack of consensus about how many stages might be involved in for a smooth process of new service development. Nevertheless, many researchers are trying to emphasize the importance of stages and figure out the optimal number of them (Bhuiyan 2011; Ulrich, Eppinger 2011; Lin, Hsieh 2011). The number of stages that are selected in the model helps the business entity to control the process, its consistency or particularity. It might be noticed in many up-to-date models of new service development. According to the type of model, the number of stages may range from 4 to 12 (Skačkauskienè et al., 2019). In the meantime, the following stages can be distinguished as the most common ones: analysis of demands and opportunities, generation and selection of ideas, business analysis, the planning process of the service, implementation of a service, delivering to the consumer.

Although the number of stages remains relatively big, the researchers are expressing their insights about the necessity to decrease the number. B. Edvardsson et al. (2013) note that the average number of stages in the models of new service development has decreased, and that number is smaller than the number of stages in the model of product development. This is also confirmed by G. L. Jamil et al. (2014). According to them, the process of new service development has significantly changed over the last decade from the linear models consisting of sequential stages to the complex models with only four general stages involved. The modern researchers also tend to develop new models with only 4 stages (Drejeris and Vestertè, 2015; Yu and Sangiorgi, 2014; Jin et al., 2014; Kindström, Kowalkowski, 2009; Dalton et al., 2009; Murthy et al., 2008; Froehle and Roth, 
2007). It can be assumed that a smaller number of stages is enough in a model for new service development. The level of particularity can be maintained by the inclusion of additional tasks or the formation of the dimensions.

Considering these aspects, it is suggested to create a model of new service development with the most common stages suggested by the scientific literature. However, it is also suggested to formulate 4 stages only: the stages of generating ideas and selection unify into one stage of preparation; the stages of internal and externals analysis unify into one stage of analysis; the stages of concept formation and testing unify into one stage of formation; the stages of implementation and launching a new service unify into one stage of realization. Considering that a model for new service development will be formed out of four stages, it is necessary to review the insights of other researchers about the actions taken at each stage. This will provide some additional information about the options of integration or dimensions.

The decisions made during the stage of preparation might determine the success of the whole process of new services development. According to M. Reinos et al. (2009), the idea of a new service is defined at this stage. Therefore, the intellectual resources are essential in order to successfully start the process of new service development. This idea is supported by M. Rapaccini et al. (2013) as they state that new ideas are being generated at this stage and the evaluation of uniqueness in the context of the overall market should be made. The need to take the prevailing conditions of the market in the account has been emphasized by F. Lin and P. Hsieh (2011). They have stated that companies must find out the tendencies of the social economy, the scope of the service and the needs of their potential customer before setting up the service. According to E. Yu and D. Sangiorgi (2018), not only the current situation of the market should be evaluated. It is important to take the competitive environment into account as well. According to the insights of the authors, it is noted that the common tasks of models such as the generation of ideas or process of selection are important in order to develop a new service. It is also suggested to assess the conditions of the market before developing a new service.

M. Froehle and A. V. Roth (2007) point out that the stage of analysis enables a business subject to critically assess the strategic, financial and market efficiency of a concept of new service. In accordance with the authors, this helps to determine whether a new service would meet the standards of the market and would it be compatible with the strategy of a company. N. Bhuiyan (2011) agrees and points out that ideas are evaluated on the basis of quantitative parameters such as profit, return on investment or sales volume during this stage. Therefore, it is a great way to assess the potential of a new service. According to J. B. Santos and M. Spring (2013), it is necessary to determine whether the resources and capabilities of a company will make the right conditions for the development of the new service. In addition to the demand to evaluate the parameters of the internal environment of a 
company that may have an impact on the development of a new service, it is noted that the authors emphasize the need to evaluate the external factors as well. D. Jin et al. (2014) suggest that proper analysis can be used in order to prevent any internal and external problems that may arise during the development process. According to F. E. Santana et al. (2016), this stage should include the analysis of the sector, the targeted segment, and the impact of direct competitors. An opportunity to evaluate the potential of technological innovation during the stage of analysis is proposed by V. A. Zeithaml et al. (2017). These approaches reveal that the tasks taken during the stage of analysis are important to critically assess the actual capabilities, resources, and potentials of a company to develop a proper new service.

According to M. Rapaccini et al. (2013), the main objectives of the stage of formation are to describe the service in a detailed way, to define the future organizational parameters of implementation, and to plan the deployment of resources. E. Yu and D. Sangiorgi (2014) state that the formation of service is considered as a key condition to ensure the quality at the point of intersection between a consumer and a subject of business. This idea is also supported by $\mathrm{O}$. Gaus et al. (2013). According to them, this stage describes the business requirements for the concept of high-value services. According to the opinion of these authors, a well-defined concept helps to achieve a better interaction between the needs of consumers and the strategic intentions of a company. The aspect of a consumer is also highlighted by H. P. Hsu (2017), who believes that consumers should be invited to play the role of a developer during the stage of formation. According to the author, the potential consumers could provide feedback about a new service, help to compare it with the services of competitors and offer some rational solutions. It is noted that authors tend to emphasize the connection between a consumer and a subject of business during the stage of formation, any observations and recommendations are given by consumers can be a good base for some improvements of service before launching it. This stage can be described as an intermediate stage when all the knowledge, information, and suggestions gained during the previous stages are used to develop the concept of a new service before it is launched during the stage of realization.

There are many different opinions about the stage of realization. The viewpoints of researchers vary according to the number of tasks that must be taken by a business subject before a new service is introduced to the market. O. Gaus et al. (2013) state that it is important to evaluate the potential demand for a new service. According to the authors, if the process of entry into the market now seems too expensive for a company, new strategies for the commercialization of entrepreneurial opportunities should be developed. In accordance with T. Burger et al. (2010); F. Lin, P. Hsieh (2011); M. Rapaccini et al. (2013), the stage of realization involves internal and external tools of communication and information. These authors state that the stage of realization might be considered as a beginning 
of monitoring when it is necessary to evaluate the process of implementation as well as the efficiency of launching. The aspect of monitoring is also highlighted by V. A. Zeithaml et al. (2017). They claim that monitoring needs to be done not only before the process of implementation but during the first cycle of launching a new service as well. According to the authors, if a customer needs six months to experience a new service, then at least six months should be taken to observe the whole process. It can be assumed that the business entity needs to carry out additional tasks of communication and monitoring that require a high level of concentration from the employees. As a result, the ability to reach the final stage of developing a new service may not always ensure the desired outcome or success of a project.

The approaches to the stages of preparation, analysis, formation, and realization of new service development models have revealed these aspects. First of all, the opinions of the authors about the actions taken at each stage, their relevancy or even their priority, tend to coincide. Therefore, this partially justifies the rationality of choosing a smaller number of stages in the model when additional tasks can be assigned. The authors indirectly emphasize the impact of employees, consumers, and competitors at each stage as well as their contribution to the process of developing a new service. Therefore, it can be presumed that it is needed to create some environments that encompass each of these subjects in a model of new service development. Finally, there are some suggestions to make an analysis during the stages of formation and realization when it is recommended to collect data while observing the actions of competitors and reactions of consumers.

\section{The Scientific Basis for The Choice of Tasks Assigned to Each Stages of a Model for New Services Development}

The assignment of additional tasks to each stage of the model for new service development is related to the need of a business subject to consider a broader range of internal and external factors during a process of new service development. For this reason, it is essential to examine the approaches to the tasks of involved stages, their number, and specificity. Considering the idea that a new model for new service development is going to be formed out of 4 stages (preparation, analysis, formation, and realization) and 3 dimensions (company, competitors, and consumers), the additional tasks will be distinguished by the way of the matrix, i.e., by the phase and by the specific dimension. This way will allow to define tasks more precisely and extend their boundaries.

The generation and selection of ideas are two very common actions during the stage of preparation. However, these actions are taking as one component in many models. For this reason, it is difficult to determine which involved subjects of this stage should perform individual actions. Although some of the new service development models do not reveal the number of actions and the role of individual components due to their abstract nature, it is noticeable that researchers are 
increasingly focusing on the specifics of such actions (see Table 2).

Table 2: Basic actions included in the preparation stage models

\begin{tabular}{|c|c|c|}
\hline \multirow[b]{2}{*}{ Dimension } & \multicolumn{2}{|c|}{ Preparation stage } \\
\hline & Author & $\begin{array}{c}\text { Basic steps assigned to the } \\
\text { phase }\end{array}$ \\
\hline Company & $\begin{array}{l}\text { M. Torney et al. (2009); } \\
\text { T. Burger et al. (2010); } \\
\text { O. Gaus et al. (2013); } \\
\text { M. Rapaccini et al. (2013); } \\
\text { R. Drejeris, J. Vesterte (2015); } \\
\text { V. A. Zeithaml et al. (2017); } \\
\text { E. Yu, D. Sangiorgi (2018). }\end{array}$ & Generation of new ideas \\
\hline Competitors & $\begin{array}{l}\text { E. Stevens, S. Dimitriadis (2005) } \\
\text { M. Reinoso et al. (2009); } \\
\text { T. Burger } \text { et al. (2010); } \\
\text { O. Gaus et al. (2013); } \\
\text { V. A. Zeithaml et al. (2017). }\end{array}$ & $\begin{array}{l}\text { Evaluation of the exclusivity of } \\
\text { ideas }\end{array}$ \\
\hline \multirow[t]{2}{*}{ Consumers } & $\begin{array}{c}\text { A. Shekar (2007); } \\
\text { M. Reinoso et al. (2009); } \\
\text { D. Jin et al. (2014); } \\
\text { H. P. Hsu (2017); } \\
\text { V. A. Zeithaml et al. (2017). }\end{array}$ & $\begin{array}{l}\text { Generating ideas (with } \\
\text { consumer involvement) }\end{array}$ \\
\hline & $\begin{array}{l}\text { M. Reinoso et al. (2009); } \\
\text { O. Gaus et al. (2013); } \\
\text { D. Jin et al. (2014); } \\
\text { V. A. Zeithaml et al. (2017). }\end{array}$ & $\begin{array}{c}\text { Evaluation of the suitability of } \\
\text { ideas }\end{array}$ \\
\hline
\end{tabular}

Source: Compiled by the author.

According to V. A. Zeithaml et al. (2017), analysis of ideas expressed by employees and consumers, research of consumer behaviors, and observation of offers made by the competitors are the most common components during the process of generation and selection of ideas. According to M. Reinoso et al. (2009), consumers can reveal their demands, express their concerns or help to identify the lack of market. Companies can use all of these points to create great competitive advantages at the beginning of the process of developing a new service.

After analyzing the basic tasks assigned to the stage of preparation, it was found out that the generation of ideas has been emphasized by many authors in the dimension of a company. The competitive environment creates a need to assess the uniqueness of ideas in the overall context of the segment in which the new service will be developed. The dimension of consumers highlights the demand to involve 
consumers in the process of ideas generating. A strong role for consumers can be easily noticed at this stage: they can help to generate ideas, evaluate the relevance of new ideas, or help a business subject to deal with any general problem of a market Meanwhile, the overall uniqueness, specificity or attractiveness of ideas are assessed in the dimension of the competitors. The results of this analysis reveal the overall sequence of tasks identified during the stage of preparation (see Figure 1).

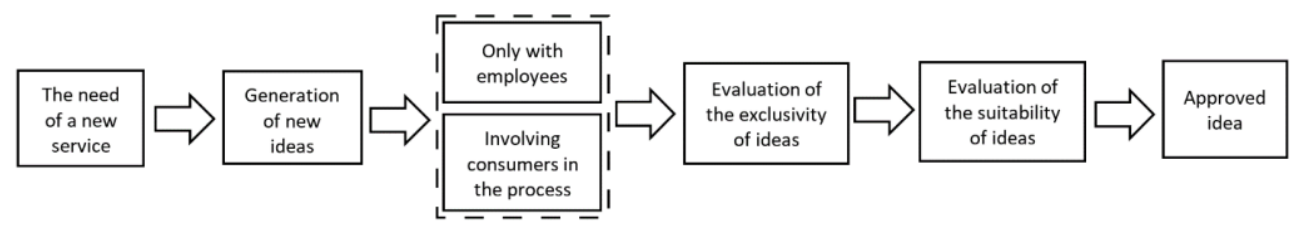

Fig. 1: The sequence of basic actions that are distinguished in the preparation phase (source: compiled by the author)

Table 3: Basic actions included in the analysis stage

\begin{tabular}{|c|c|c|}
\hline \multirow{2}{*}{ Dimension } & \multicolumn{2}{|c|}{ Analysis stage } \\
\hline & Authors & Basic steps assigned to the phase \\
\hline \multirow[b]{2}{*}{ Company } & $\begin{array}{l}\text { C. M Froehle, A. V. Roth (2007); } \\
\text { J. B. Santos, M. Spring (2013); } \\
\text { V. A. Zeithaml et al. (2017). }\end{array}$ & $\begin{array}{l}\text { Assessment of employee } \\
\text { competence }\end{array}$ \\
\hline & $\begin{array}{l}\text { M. Reinoso et al. (2009); } \\
\text { F. Lin, P. Hsieh (2011); } \\
\text { J. B. Santos, M. Spring (2013); } \\
\text { V. A. Zeithaml et al. (2017). }\end{array}$ & $\begin{array}{l}\text { Economic reasonableness / cost- } \\
\text { benefit analysis }\end{array}$ \\
\hline Competitors & $\begin{array}{l}\text { E. Stevens, S. Dimitriadis (2005); } \\
\text { M. Reinoso et al. (2009); } \\
\text { F. Lin, P. Hsieh (2011); } \\
\text { O. Gaus } \text { et al. (2013); } \\
\text { F. E. Santana et al. (2016). }\end{array}$ & Competitive / Market Analysis \\
\hline Consumers & $\begin{array}{l}\text { E. Stevens, S. Dimitriadis (2005) } \\
\text { O. Gaus et al. (2013); } \\
\text { E. Yu, D. Sangiorgi (2014); } \\
\text { D. Jin et al. }(2014) ; \\
\text { F. E. Santana et al. }(2016) ; \\
\text { H. P. Hsu (2017). }\end{array}$ & $\begin{array}{c}\text { Identifying consumer needs in the } \\
\text { context of the service being } \\
\text { developed }\end{array}$ \\
\hline
\end{tabular}

Source: Compiled by the author.

The process of identifying the demand for a new service might be considered as the beginning of the preparation stage. Any other actions related to the generation and evaluation of ideas are carried out later. Finally, the best idea for a new 
potential service is chosen.

It is noticeable that the stage of analysis is also not divided into a wider range of separate tasks (e. g., internal analysis, external analysis, etc.). However, the ideas about the necessity to carry out a broad-based analysis might be found in many works of research (see Table 3).

The opinions of researchers about the tasks assigned to this stage have revealed that a broader spectrum of analysis could provide more insights into in-house processes and the market situation. In this case, the competitive aspects, socialeconomic or technological trends would be reviewed, and the specific targeted segment could be investigated (see Figure 2).

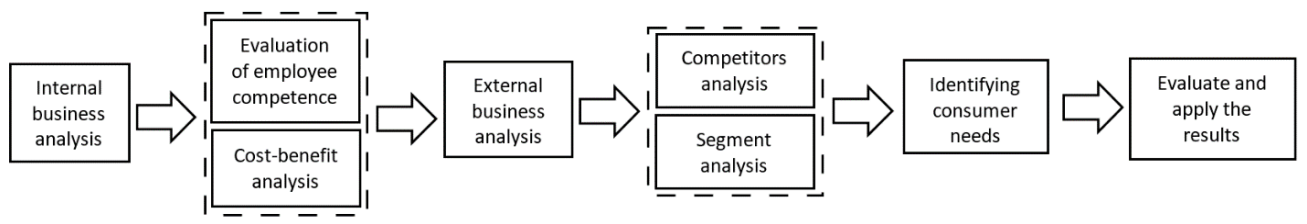

Fig. 2: The sequence of basic actions that are distinguished in the analysis phase (source:

compiled by the author)

Therefore, the stage of analysis helps company to assess the potential of a newly developing service in one particular market. The evaluation of the results under the criteria such as the compatibility with the needs of the consumers, the compatibility with the overall strategy of the company, or the financial advantages helps to continue the proper process of new service development.

The stage of formation can be identified as one of the widest stages in terms of the number of assigned tasks and the number of internal and external subjects that are needed to accomplish those tasks. According to V. A. Zeithaml et al. (2017), this stage of service development should involve everyone who is interested in a new service: consumers, contact persons, as well as, specialists of marketing and human resources. It can be assumed that the stage of formation includes the basic tasks related to the formation of concept and its testing and parallel tasks such as staff training, additional business analysis or improvements of service concept (see Table 4).

Regarding consumer engagement, some authors (Reinoso et al. 2009; Zeithaml et al., 2017; Yu and Sangiorgi, 2014; Yu and Sangiorgi, 2018.) indicate that this component is necessary due to the initial testing of the conceptual service and additional approaches that can be used for the successful development of service solutions. According to H. P. Hsu (2017), sharing knowledge and discussion is essential in order to transfer consumer knowledge to an organization. This enables the company to make full use of the information, suggestions, and observations that have been received. The author states that the engagement of consumers in the team of service development can effectively reduce service development time if the ideas are presented during the beginning of the development process. 
Table 4: Basic actions included in the formation stage

\begin{tabular}{|c|c|c|}
\hline \multirow{2}{*}{ Dimension } & \multicolumn{2}{|c|}{ Formation stage } \\
\hline & Authors & Basic steps assigned to the phase \\
\hline \multirow[t]{3}{*}{ Company } & $\begin{array}{l}\text { F. Lin, P. Hsieh (2011); } \\
\text { B. Edvardsson et al. (2013); } \\
\text { O. Gaus et al. (2013); } \\
\text { R. Drejeris, J. Vesterte (2015); } \\
\text { F. E. Santana et al. (2016); } \\
\text { V. A. Zeithaml et al. (2017). }\end{array}$ & Formation of a conceptual service \\
\hline & $\begin{array}{c}\text { Johnson et al. (2000); } \\
\text { A. Shekar (2007); } \\
\text { C. M Froehle, A. V. Roth (2007); } \\
\text { V. A. Zeithaml et al. (2017); } \\
\text { H. P. Hsu (2017). }\end{array}$ & Employee engagement \\
\hline & $\begin{array}{l}\text { E. Stevens, S. Dimitriadis (2005); } \\
\text { C. M Froehle, A. V. Roth (2007); } \\
\text { M. Reinoso et al. (2009); } \\
\text { C. Riedl et al. (2011); } \\
\text { V. A. Zeithaml et al. (2017); } \\
\text { H. P. Hsu (2017). }\end{array}$ & Staff training \\
\hline Competitors & $\begin{array}{l}\text { F. Lin, P. Hsieh (2011); } \\
\text { O. Gaus et al. (2013). }\end{array}$ & Additional business analysis \\
\hline \multirow[t]{2}{*}{ Consumers } & $\begin{array}{l}\text { D. Jin et al. (2014); } \\
\text { O. Gaus et al. (2013); } \\
\text { E. Yu, D. Sangiorgi (2014); } \\
\text { V. A. Zeithaml et al. (2017); } \\
\quad \text { H. P. Hsu (2017). }\end{array}$ & Consumer involvement \\
\hline & $\begin{array}{l}\text { D. Jin et al. (2014); } \\
\text { E. Yu, D. Sangiorgi (2014); } \\
\text { V. A. Zeithaml et al. (2017); } \\
\text { H. P. Hsu (2017). }\end{array}$ & $\begin{array}{c}\text { Evaluation of Consumer } \\
\text { Proposals }\end{array}$ \\
\hline
\end{tabular}

Source: Compiled by the author.

The opinions of authors about the additional tasks assigned to the stage of formulation have revealed the following aspects: 1) it was noted that some authors (Stevens, Dimitriadis 2005 and Froehle, Roth 2007) point out that the process of staff training should be done throughout the whole process of developing new services, 2) the demand to evaluate the external factors in the competitive environment of this stage is lower than in the previous stages. It can be assumed that it is necessary to use all human resources for the completion of the basic actions first during the stage of formation. Any other related tasks might be completed 
afterward, 3) it was noted that when it comes to consumer involvement, the authors distinguish between the need for their involvement in the testing of a conceptual service and the evaluation of their proposals after this process. By applying this analogy, it can be assumed that it would be useful for employees to get involved not only by making theoretical suggestions for the concept of a new service, but also by participating in a pilot simulation of a new service (only between employees) (see Figure 3).

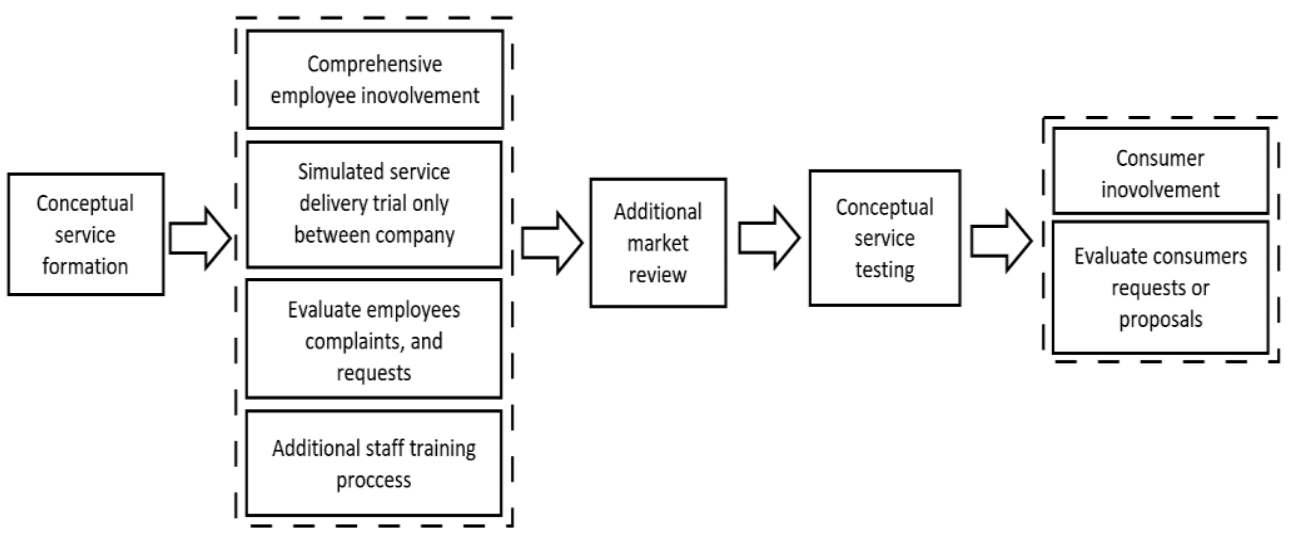

Fig. 3: The sequence of basic actions that are distinguished in the formation phase (source: compiled by the author)

In the final stage of realization, a new service is being implemented, after the final version of the conceptual service has been approved and its major shortcomings have been fixed. There are only a few basic tasks at this stage (see Table 5).

However, there are discussions about the process of completion of this stage. The authors argue whether the development of a new service will be completed by the process of launching or the additional actions of monitoring should be taken in order to make some minimal adjustments (see Figure 4).

From the perspective of developing a new service, additional questions arise regarding some of the authors' monitoring activities. First of all, it is not entirely clear in which part of the process the development of the new service ends and the provide starts. Secondly, it is not clear whether such monitoring activities are focused on the short or long term period. Finally, there is a lack of information on the purpose of the knowledge gained during monitoring. Whether to improve the deficiencies of a service already introduced on the market (despite the fact that it has already been introduced) or vice versa, use it to create a new service. It is important to consider each of these problematic aspects in the new service development model. 
Table 5: Basic actions included in the realization stage

\begin{tabular}{|c|c|c|}
\hline \multirow{2}{*}{ Dimension } & \multicolumn{2}{|c|}{ Realization stage } \\
\hline & Authors & Basic steps assigned to the phase \\
\hline \multirow[t]{2}{*}{ Company } & $\begin{array}{l}\text { M. Reinoso et al. (2009); } \\
\text { O. Gaus et al. (2013); } \\
\text { M. Rapaccini et al. (2013); } \\
\text { E. Yu, D. Sangiorgi (2014); } \\
\text { F. E. Santana et al. (2016); }\end{array}$ & Launch \\
\hline & $\begin{array}{l}\text { T. Burger et al. (2010); } \\
\text { F. Lin, P. Hsieh (2011); } \\
\text { M. Reinoso et al. (2009); } \\
\text { M. Rapaccini et al. (2013); } \\
\quad \text { H. P. Hsu (2017). }\end{array}$ & Marketing planning \\
\hline Competitors & $\begin{array}{c}\text { A. Shekar (2007); } \\
\text { O. Gaus et al. (2013); } \\
\text { V. A. Zeithaml et al. (2017). }\end{array}$ & Evaluate the reaction of competitors \\
\hline \multirow[t]{2}{*}{ Consumers } & $\begin{array}{c}\text { O. Gaus et al. (2013); } \\
\text { H. P. Hsu (2017); } \\
\text { V. A. Zeithaml et al. (2017). }\end{array}$ & Test of a new service \\
\hline & $\begin{array}{l}\text { M. Torney et. al. (2009); } \\
\text { F. Lin, P. Hsieh (2011); } \\
\text { O. Gaus et al. (2013); } \\
\text { B. Edvardsson et al. (2013); } \\
\text { E. Yu, D. Sangiorgi (2018). }\end{array}$ & Post-launch review \\
\hline
\end{tabular}

source: compiled by the author.

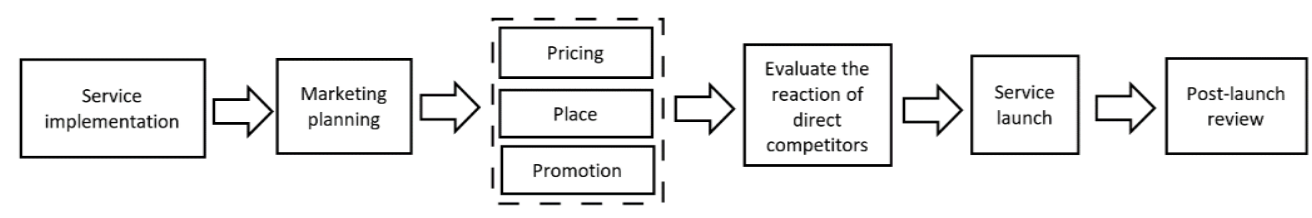

Fig. 4: The sequence of basic actions that are distinguished in the realization phase (source: compiled by the author)

Based on the results of the analysis, it is possible to formulate a conceptual diagram of the new service development model, which distinguishes the general layout of the dimensions, stages and actions assigned to them (see Figure 5).

This principal scheme is a matrix structure, so it has some advantages:

1. This allows to analyze each component at different stages of its development and vice versa in different dimensions.

2. This allows the business to access the vast amount of information that is 
being processed at each step in the growing amount of data related to the development and launch of new services.

3. The model allows to evaluate not only the company's ability to create a new service but also the external risks: components can be explored in the internal context of the company and also in the context of competitors and consumers, in order to highlight the influence of external factors on the process.

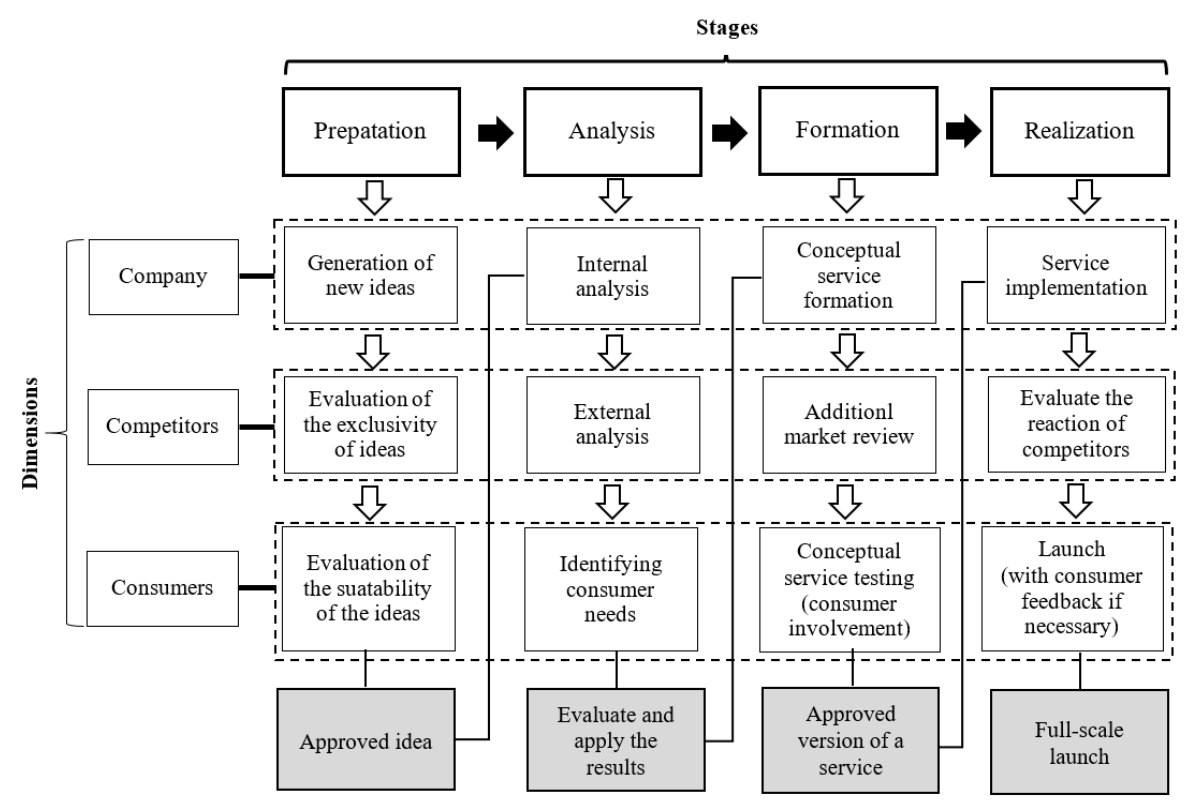

Fig. 5: Principal scheme of the new service development (source: compiled by the author)

\section{Conclusions and Directions for Further Research}

The need to develop a model for the development of new services initiates the preparatory actions to choose a type of model, as well as, all right actions and stages in order to form an appropriate structure. The process of formation is a challenge that could highlight the distinctive features of this model and its benefits for modern businesses of the service sector. So the purpose of this study is to broaden the approach to the rationale for choosing the type, stages, and actions of the previously developed model for developing new services (Skačkauskienè et al. 2019).

Benchmarking analysis has revealed that the complex / comprehensive type of model can be considered as the most convenient type in order to create a new model. The indefinite structure of this type, the ability to freely positioning the actions and integrate some external actions that might be relevant to modern companies have determined the choice of this type of model as a base for a new development of a new model. Some researches take complex models as not an appropriate tool 
because of the need for a high level of specific application knowledge. However, it can be assumed that the required amount of knowledge depends on the structure of the model, the assigned tasks, and other aspects such as the nature of a service, the overall preparation or previous experience of a business subject. The guidance of the application is going to be developed in order to make the use of the new model for service development easier.

The opinions of the authors about the actions taken at each stage, their relevancy or even their priority, tend to coincide. Therefore, this partially justifies the rationality of choosing a smaller number of stages in the model when additional tasks / actions can be assigned.

This type of new service design model structure would allow businesses to assess not only the internal factors involved in this process, but also the external aspects: consumer needs, their involvement in the process, the reaction of competitors, and so on.

Future research will assess whether the design of a new service development model is appropriate to the needs of business services companies (assessing individual components, opportunities for improvement, model adaptability), as well as identifying additional performance enhancements for the whole new service development process using the PERT method (Program Evaluation and Review Technique) approach.

\section{References}

Alam, I., and Perry, C. (2002). A customer-oriented new service development process. Journal of Services marketing, 16(6), 515-35.

Bhuiyan, N. (2011). A framework for successful new product development. Journal of Industrial Engineering and Management, 4(4), 746-770.

Boguslauskas, V. (2007). Ekonometrika. Kaunas: Technologija.

Briscoe, G., Keränen, K., and Parry, G. (2012). Understanding Complex Service Systems Through Different Lenses: An Overview. European Management Journal, 30(5), 418-426.

Bullinger, H. and Schreiner, P. (2006). Service Engineering: Ein Rahmenkonzept für die systematische Entwicklung von Dienstleistungen. Service Engineering. Heidelberg: Springer Verlag.

Burger, T., Kim, K. and Meiren, T. (2010). A Structured Test Approach for Service Concepts. International Journal of Service Science, Management, Engineering, and Technology, 1(4), 12-21. 
Chawla, S., Gupta, N., and Singla, R. (2012). LOQES: Model for Evaluation of Learning Object, International Journal of Advanced Computer Science and Applications, 3(7), 73-79.

Cocca, S., Franke, A., and Schell, S. (2015). Agile New Service Development in an Interdisciplinary Context. Technology Innovation Management Review, 5, 33-45.

Dalton, R., Lynch, P., and Lally, A. (2009). Towards a Model of New Service Development for Differentiated Tourism Services. $5^{\text {th }}$ Toursim and Hospitality Research in Ireland Conference (THRIC), 1-14.

Drejeris, R. and Vesterte, J. (2015). New Public Service Development: Identifying Elements of Process Model. Journal of System and Management Sciences, 5(3), $65-$ 83.

Edvardsson, B., Meiren, T., Schaefer, A., and Witell, L. (2013). Having a strategy for new service development - does it really matter? Journal of Service Management, 24(1), 25-44.

Froehle, C. and Roth, A. (2007). A Resource-Process Framework of New Service Development. Production and Operation Management, 16(2), 169-188.

Gaus, O., Neutschel, B., Raith, M. G., and Vajna, S. (2013). How Designed Communication Supports New Product \& Service Development. iBusiness, 5, 10-17.

Hsu, P. H. (2017). Constructing a Innovative Service Development Process Base on Ethics. International Journal of Social Science and Humanity, 7(2), 76-81.

Jamil, G. L., Malheiro, A., and Ribeiro F. (2014). Rethinking the Conceptual Base for New Practical Applications in Information Value and Quality. USA: Information Science Reference.

Jin, D., Chai, K., and Tan, K. (2014). New service development maturity model. Managing Service Quality: An International Journal, 24(1), 86-116.

Johnson, S. P., Menor, L. J., Roth, A.V., and Chase, R. B. (2000). A critical evaluation of the new service development process: integrating service innovation and service design. In: Fitzsimmons, J.A., Fitzsimmons, M.J. (Eds.), New Service Development-Creating Memorable Experiences. Sage Publications, Thousand Oaks. 
Karniel, A., and Reich. Y. (2013). Multi-level modelling and simulation of new product development processes. Journal of Engineering Design, 24(3), 185-210.

Kanišauskas, S. (2013). Filosofinès socialinio modeliavimo problemos: teorija, praktika, siekiai, vertybès. Vilnius: Mykolo Romerio universitetas.

Katinienè, A. (2018). Organizacijos darbuotojų žinių sinergijos vertinimas. Daktaro disertacija. Vilnius: Technika.

Kindström, D., and Kowalkowski, C. (2009). Development of industrial service offerings: a process framework. Journal of service management, 20(2), 156-172.

Kopańska, A. (2017). Determinant of cities and towns spending on culture. Analysis for Poland. 27th European Association for Research on Services (RESER) Conference Bilbao, 211-229.

Kumar, R., and Singh, S. P. (2017). Optimal selection of multi-criteria unequal area facility layout problem: an integer linear program and Borda-Kendall-based method. International Journal of Business and Systems Research, 11(1/2), 62-81.

Lin, F., and Hsieh, P. (2011). A SAT view on new services development, Service Science, 3(2), 141-157.

Murthy, D. N. P., Rausand, M., and Qsteras, T. (2008). Product Reliability Specification and Performance: new product developement. Springer US.

Pilkauskas, V. (2011). Procesų modeliavimas ir nuotolinis valdymas. Vilnius: TEV.

Rapaccini, M., Saccani, N., Pezzotta, G., Burger, T., and Ganz, W. (2013). Service development in product-service systems: a maturity model. The Service Industries Journal, 33(3-4), 300-319.

Reinoso, M., Lersviriyajitt, S., Khan, N., Choonthian, W., and Laosiripornwattana, P. (2009). New Service Development: Linking Resources, Processes, and the Customer. PICMET 2009 Proceedings, August 2-6, Portland, Oregon USA, 29212932.

Santana, F. E., Lemos, L. L., Montanha, I. R., Ferreira, M. G. G., and Forcellini, F. A. (2016). A Service Development Process Framework for Services Including People with Disabilities. Proceedings of $5^{\text {th }}$ Service Design and Innovation conference, 403-414. 
Santos, J. B., and Spring, M. (2013). New service developement: managing the dynamic between services and operations resources. International Journal of operations and production management, 33(7), 800-827.

Skačkauskienė, I., Švogžlys, P. and Majdzik, A. L. (2019) Formation of a Conceptual Model for New Services. Polish Journal of Management Studies, 19(2), 374-384.

Stevens, E. and Dimitriadis, S. (2005). Managing the new service development process: towards a systemic model. European Journal of Marketing, 39(1/2), 175198.

Ulrich, K. T., and Eppinger, S. D. (2011). Product Design and Development, 5th ed. New York: McGraw-Hill.

Wang, P. P., Ming, L. D., Kong. F. B., Wang. L., and Wu, Z. Y. (2011). Modular Development of Product Service Systems. Concurrent Engineering: Research and Applications, 19(1), 85-96.

Wynn, D. C., and Clarkson P. J. (2018). Process models in design and development. Research in Engineering Design, 29, 161-202.

Yu, E. and Sangiorgi, D. (2014). Service Design as an Approach to New Service Development: Reflections and Future Studies. Proceedings of the $4^{\text {th }}$ Service Design and Service Innovation Conference, 194-204.

Yu, E., and Sangiorgi, D. (2018). Service Design as an Approach to Implement the Value Cocreation Perspective in New Service Development. Journal of Service Research, 21(1), 40-58.

Zanker, J. H., and Mallett, R. (2013). How to do a Rigorous, Evidence-focused Literature Review in International Development: A Guidance Note. Available from: https://www.odi.org/sites/odi.org.uk/files/odi-assets/publications-opinionfiles/8572.pdf

Zeithaml, V. A., Bitner, J. M., and Gremler, D. D. (2017). Services marketing: Integrating customer focus across the firm, 7th ed. New York: McGraw-Hill. 